\title{
CXC chemokine receptor 4 expressed in T cells plays an important role in the development of collagen-induced arthritis
}

\author{
Soo-Hyun Chung ${ }^{1}$, Keisuke Seki ${ }^{1}$, Byung-II Choi ${ }^{1,2}$, Keiko B Kimura ${ }^{3}$, Akihiko Ito ${ }^{3}$, Noriyuki Fujikado', Shinobu Saijo ${ }^{1}$,
} Yoichiro Iwakura ${ }^{1,4^{*}}$

\begin{abstract}
Introduction: Chemokines and their receptors are potential therapeutic targets in rheumatoid arthritis (RA). Among these, several studies suggested the involvement of CXC chemokine 4 (CXCR4) and its ligand CXC ligand 12 (SDF1) in RA pathogenesis. However, the role of these molecules in T-cell function is not known completely because of embryonic lethality of Cxcr4- and Cxc/12-deficient mice. In this report, we generated T cell-specific Cxcr4-deficient mice and showed that the CXCR4 in T cells is important for the development of collagen-induced arthritis (CIA).

Methods: T cell-specific Cxcr4-deficient mice were generated by using the Cre-loxP system. Mice harboring loxP sites flanking exon 2 of the $C x c r 4 g e n e\left(C x c r 4^{f l o x}\right.$ flox $)$ were generated by homologous recombination and crossed with Cre transgenic mice expressing Cre recombinase under the control of $L C k$ promoter (CxCr4 ${ }^{+/+} / L C k$-Cremice) to generate T cell-specific Cxcr4-deficient mice (Cxcr4tfoxflox/LCk-Cre mice). CIA was induced by immunization with chicken type II collagen and Complete Freund's Adjuvant (CFA).
\end{abstract}

Results: The incidence, but not the severity, of CIA was significantly reduced in CXCr4tox/flox/LCk-Cre mice compared with $C \times C r 4^{+/+} / L C k$-Cre mice. We found that the expression of CXCR4 was enhanced in activated T cells, and the migration of Cxcr4-deficient T cells toward SDF-1 was severely impaired. However, antibody production, cellular proliferative response, and cytokine production on treatment with type II collagen (IIC) were normal in these knockout mice, suggesting that CXCR4 is not involved in T-helper functions. Interestingly, the proportion of CXCR4expressing $T$ cells was much increased in affected joints compared with that in draining lymph nodes in CIAinduced mice, and distribution of Cxcr $4^{\text {flox/flox}} / \mathrm{LCk}$-Cre mouse-derived T cells into affected joints was suppressed compared with that in $\mathrm{CxCr} 4^{+/+} / \mathrm{LCk}$-Cre T cells.

Conclusions: These results indicate that CXCR4 expression in T cells is important for the development of CIA, by recruiting activated T cells toward inflammatory sites, and suggest that CXCR4 is a good target for the treatment of RA in humans.

\section{Introduction}

Rheumatoid arthritis (RA) is an autoimmune disease affecting about $1 \%$ of the world population and characterized by chronic inflammation of multiple joints, proliferation of the synovial cells, and destruction of the cartilage and bone of the affected joints. Genetic factors and environmental agents are assumed to be involved in

\footnotetext{
* Correspondence: Iwakura@ims.u-tokyo.ac.jp

'Laboratory of Molecular Pathogenesis, Center for Experimental Medicine and Systems Biology, Institute of Medical Science, University of Tokyo, 4-6-1 Shirokanedai, Minato-ku, Tokyo 108-8639, Japan

Full list of author information is available at the end of the article
}

the development of disease, but the precise etiopathogenesis has not been elucidated completely $[1,2]$.

To elucidate the complex RA pathogenesis, various disease models of RA have been developed $[1,3]$. Collagen-induced arthritis (CIA), one of the well-established animal models of RA, can be induced in mice by immunization with type II collagen (IIC) $[4,5]$. Although the concept that humoral and cellular immunity to IIC is crucial for the development of CIA is widely accepted, multiple chemokines and cytokines are also important for the pathogenesis. 
CXC chemokine receptor (CXCR) 4 is a chemokine receptor expressed in various cells of the immune system and the central nervous system [6-8]. CXCR4 mediates migration of resting hematopoietic progenitors and B cells in response to its ligand, CXC ligand 12 (SDF-1), which is involved in various phenomena such as hematopoiesis and the development or survival of B cells $[7,9]$. Furthermore, the SDF-1-CXCR4 system is also suggested to be involved in the $\mathrm{T}$-cell receptor (TCR) signaling [10] or cell migration or both [6].

Accumulating evidence suggests the involvement of the SDF-1-CXCR4 system in the pathogenesis of RA. CXCR4-expressing $\mathrm{CD} 4{ }^{+} \mathrm{CD} 45 \mathrm{RO}^{+} \mathrm{T}$ cells are abundantly detected in the synovial tissues of RA patients [11]. T helper (Th) 1 cells, which are believed to be involved in the pathogenesis in part, are attracted by RA synovial fluid, and chemotaxis is interfered by anti-SDF1 antibody in vitro [12]. SDF-1 is expressed at high levels in RA synovial tissues [13]. Furthermore, it is suggested that CXCR4 is important for T-cell retention in RA synovial tissues [11]. However, the importance of $\mathrm{T}$ cell-expressing CXCR4 in the development of RA and the functional role of CXCR4 in $\mathrm{T}$ cells still remain obscure, because many other cells, such as B cells and osteoclasts, also express CXCR4. Because null-knockout mice of $\mathrm{Cxcr} 4$ and $\mathrm{Cxcl12}$ genes are embryonic lethal [14-16], it was difficult to elucidate the roles of this molecule in different cell types in the pathogenesis of diseases.

In this study, we generated $\mathrm{T}$ cell-specific Cxcr4deficient mice and showed that the incidence of CIA was significantly decreased in these mice. Moreover, we confirmed that $\mathrm{T}$ cells migrate toward SDF-1 in a CXCR4-dependent manner in vitro, and CXCR4-expressing $\mathrm{T}$ cells were enriched in the affected joints during the development of CIA, suggesting involvement of T cell-expressing CXCR4 in the development of RA.

\section{Materials and methods}

\section{Mice}

Cxcr $4^{\text {flox } / \text { flox }}$ mice were generated as described previously in detail [17]. In brief, $4.7 \mathrm{~kb}$ of mouse genomic fragment containing the second exon of the Cxcr4 gene was floxed by two loxP sites containing neomycin-resistant $\left(\mathrm{Neo}^{\mathrm{r}}\right)$ gene, and the diphtheria toxin A (DT-A) gene was inserted to the upstream of the $5^{\prime}$ arm for negative selection (Figure 1a). Targeted E14.1 ES cells were aggregated with C57BL/6J embryos, and the chimeric mice were crossed with C57BL/6J mice to obtain a germline-transmitted mouse. After intercrossing this mouse with proximal Lck promoter (Lck)-Cre transgenic mice (C57BL/6J background, kindly provided by Dr. Junji Takeda, Osaka University) [18], Cxcr $4^{f l o x /+} / L c k-C r e$ mice were backcrossed to the DBA/1J mice (Charles
River Laboratories) for eight generations. Then they were intercrossed to obtain Cxcr flox/flox /Lck-Cre, $C x c r 4^{+/+} / L c k-C r e$, and Cxcr $f^{\text {flox/flox }}$ mice on the DBA/1J background. Unless otherwise indicated, $\mathrm{Cxcr} 4^{+/+} / \mathrm{Lck}-$ Cre mice on the DBA/1J background were used as controls. Age- and gender-matched mice were used for all experiments. Mice were housed under specific pathogen-free conditions in an environmentally controlled clean room at the Center for Experimental Medicine and Systems Biology, Institute of Medical Science, University of Tokyo. Experiments were performed according to the ethical guidelines for animal experimentation, which was approved by the Institutional Animal Care and Use Committee (reference number A17-5) and the safety guidelines for gene manipulation.

\section{Collagen-induced arthritis}

CIA was induced as described previously [19]. In brief, mice were immunized with $100 \mu \mathrm{l}$ of $2 \mathrm{mg} / \mathrm{ml}$ chicken IIC (Sigma-Aldrich, St. Louis, MO) emulsified in Complete Freund's Adjuvant (CFA; Difco) intradermally at three sites near the base of the tail on day 0 . On day 21 , the mice were given booster injection with the same amount of IIC/CFA intradermally near the former injection sites.

\section{Clinical and histologic assessment of arthritis}

Development of arthritis by macroscopic evaluation was determined as described previously [19]. For histologic assessment of arthritis, limbs were fixed with $10 \%$ neutral formalin and were decalcified with $5 \%$ formic acid 60 days after the first immunization, and embedded in paraffin. Then $5-\mu \mathrm{m}$ slices were prepared. Sections were stained with hematoxylin-eosin (H\&E).

\section{Analysis on IIC-specific T-cell response}

IIC-specific T-cell proliferative response was performed as previously described [20]. In brief, inguinal and infraaxillary lymph nodes (LNs) were harvested from mice 7 days after the primary immunization with chicken IIC with CFA. A single-cell suspension was prepared, and 3 $\times 10^{5}$ cells/well in 96-well flat-bottom plates (Falcon) were cultured in the absence or presence of 50,100 , or $200 \mu \mathrm{g} / \mathrm{ml}$ of heat-denatured chicken IIC at $37^{\circ} \mathrm{C}$ for 72 hours, followed by incorporation of $25 \mu \mathrm{Ci} / \mathrm{ml}\left[{ }^{3} \mathrm{H}\right]$-thymidine (Amersham, Chalfont St. Giles, Buckinghamshire, UK) for 6 hours. Then, cells were harvested with a Micro 96 cell harvester (Skatron, Lier, Norway), and radioactivity was measured with Micro Beta (Pharmacia Biotech, Piscataway, NJ). The concentrations of IL-17A and IFN- $\gamma$ in the culture supernatant were determined by commercially available ELISA kits (Ready-Set-Go! Mouse IL-17A ELISA from eBioscience and Mouse IFN- $\gamma$ ELISA kit from R\&D systems). 
A

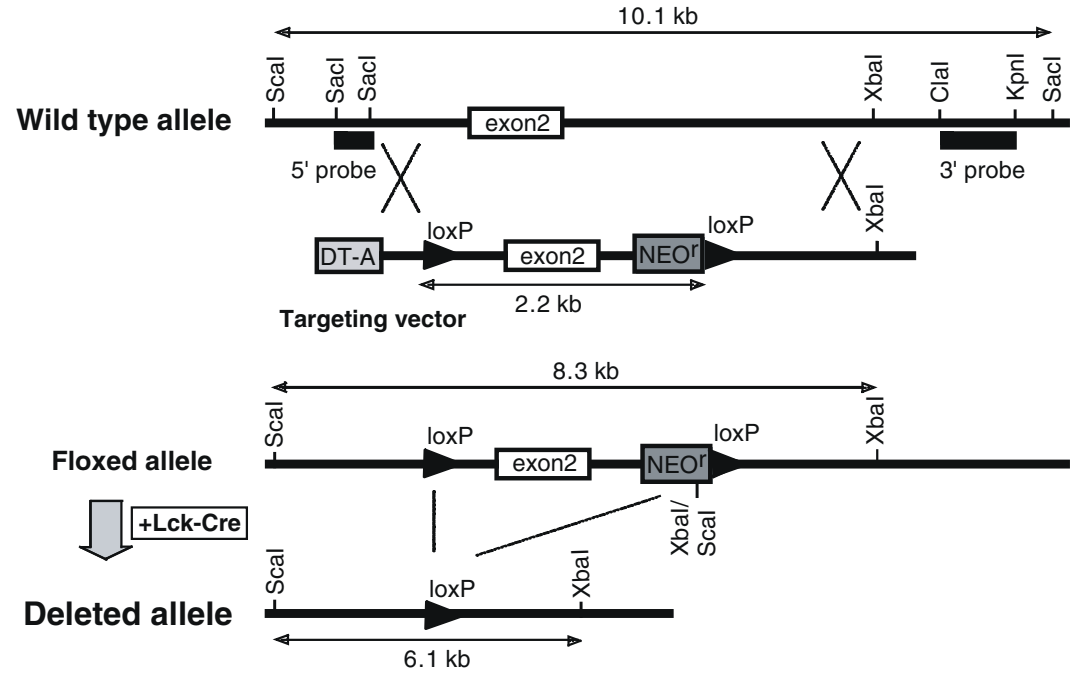

B

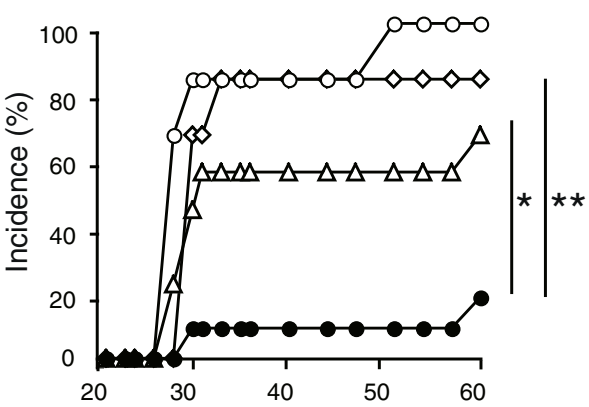

C
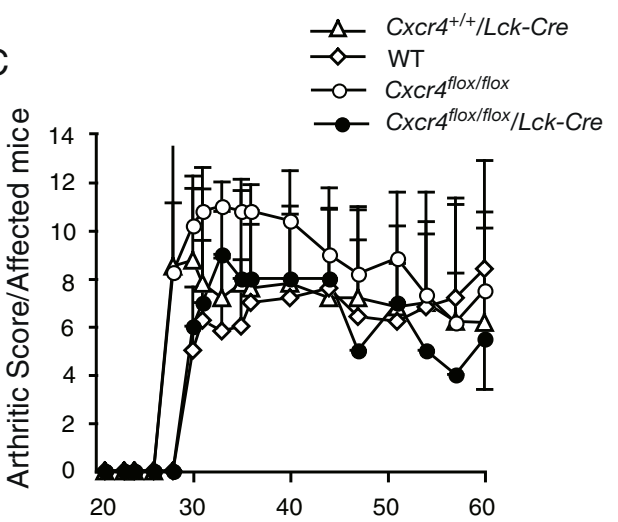

D

Cxcr4+/+Lck-Cre, developed

Cxcr4flox/flox/Lck-Cre, not developed

Cxcr4tlox/flox/Lck-Cre, developed
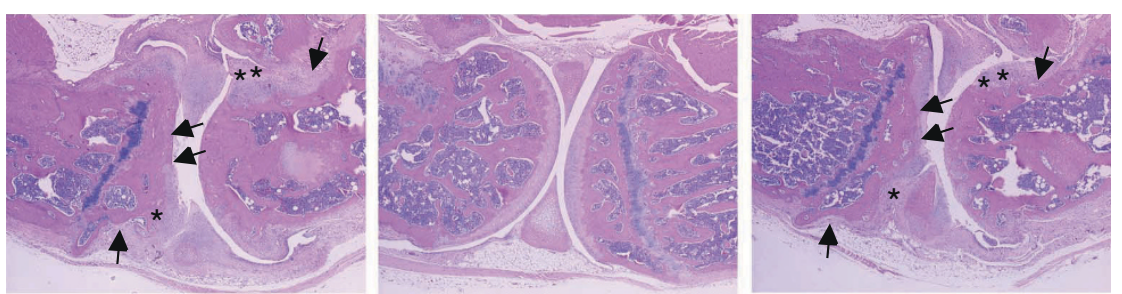

Figure 1 The development of CIA is suppressed in $C x c r 4^{\text {flox/flox }} /$ Lck-Cre mice. (a) Targeting strategy for the generation of conditional knockout mice of Cxcr4. T cell-specific Cxcr4-targeted (CXCr4tox/flox/Lck-Cre) mice were generated as described in Materials and methods. (b) Incidence of CIA. (c) Severity of CIA. Mice were immunized with chicken IIC emulsified with CFA intradermally at triple sites into the back on day 0 and 21. Open circles, $C x C r 4^{+/+}$mice $(n=6)$; open diamonds, $C x c r 4^{\text {floxflox }}$ mice $(n=6)$; open triangles, $C x c r 4^{+/+} / L c k-C r e$ mice $(n=9)$; solid circles, Cxcr4 floxflox $/ L C k$-Cre mice $(n=11)$. Representative data obtained from two independent experiments are shown. Averages and SDs are indicated

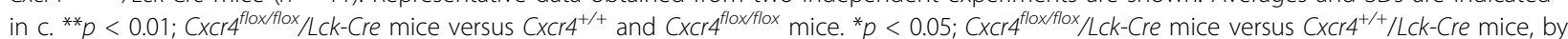
$\chi^{2}$-test. (d) Histologic changes of the joints after induction of CIA. After the inspection of the arthritis development shown in b and c, hindlimbs were removed at 60 days after the first immunization, and paraffin sections of joints were stained with hematoxylin and eosin. The histology of the joint of a IIC-immunized and arthritis-developed CXCr4 ${ }^{+/+} / L C k$-Cre mouse ( $C x C r 4^{+/+} / L c k$-Cre, developed) shows severe erosion of the bone (arrows) and hyperplasia of synovial membrane $\left(^{*}\right)$, whereas no such abnormalities are seen in the joints of Cxcr4tox/flox/LCk-Cre mice that did not

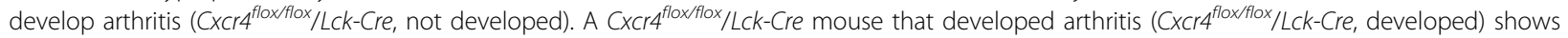
severe bone erosion (arrows) and pannus-like structure $\left(^{*}\right)$, comparable to those of control mice. $\times 40$. Typical histologies are shown in 22 representative sections from three mice for each group. 


\section{Measurement of collagen-specific lg titers}

Ig titers in serum were determined, as previously described [20]. In brief, 60 days after the first immunizations with IIC/CFA, serum was collected. Falcon 3912 Micro Test III Flexible Assay Plates (BD Biosciences, San Diego, CA) were coated with $0.1 \mathrm{ml} /$ well of $10 \mu \mathrm{g} / \mathrm{ml} \mathrm{IIC}$ in PBS at $4{ }^{\circ} \mathrm{C}$ overnight. After washing with PBS, serially diluted serum samples were applied and incubated at room temperature for 1 hour. Then the wells were washed with PBS-0.05\% Tween 20 , followed by the addition of alkaline phosphatase-conjugated goat anti-mouse IgG and IgM (Zymed, San Francisco, CA). Alkaline phosphatase activity was measured with Substrate Phosphatase SIGMA104 (Sigma-Aldrich) as the substrate. Results are expressed by the absorbance at $415 \mathrm{~nm}$.

\section{In vitro chemotaxis assay}

Migration of T cells was analyzed as described elsewhere [21]. In brief, $T$ cells were purified from single-cell suspension of LNs by removing B cells with microbead-conjugated anti-mouse B220 antibody (Miltenyi Biotec) and an Auto-MACS (Miltenyi Biotec). T cells were suspended in RPMI 1640 with $1 \% \mathrm{FCS}$, and $3 \times 10^{6}$ cells were applied onto micropore filters $(3.2 \mu \mathrm{m}$ diameter, $3-\mu \mathrm{m}$ pore polycarbonate transwell culture insert; ChemoTx, Gaithersburg, NeuroProbe). In the lower chamber, SDF1a was supplemented in a concentration of $100 \mathrm{ng} / \mathrm{ml}$ and cultured for 2.5 hours in a $5 \% \mathrm{CO}_{2}$ incubator at $37^{\circ} \mathrm{C}$. Then migrated cells in the lower chamber were counted with a flow cytometer (FACS Calibur; Becton Dickinson, San Jose, CA) for 30 seconds with medium flow speeds. All points were determined in triplicate.

\section{In vivo migration assay}

T-cell migration in vivo was analyzed by the transfer of radioisotope-labeled $\mathrm{T}$ cells as follows. Recipient mice were immunized twice with IIC 3 weeks and 1 week before the T-cell transfer. As the donors, $\mathrm{CxCr}^{+/+} / \mathrm{Lck}$ Cre mice and Cxcr $4^{f l o x / f l o x} / L c k$-Cre mice were immunized only once, 1 week before transplantation. Then LNs and spleens were harvested from the donor mice, and $\mathrm{T}$ cells were purified by using anti-Thy1.2 microbeads (Miltenyi Biotech) and Auto-MACS. T cells from each genotype were labeled with either ${ }^{51} \mathrm{Cr}$ (PerkinElmer Life \& Analytical Sciences) or ${ }^{111}$ In-oxin (Nihon Medi+physics) as previously described $[22,23,23,24]$. In brief, T cells were cultured with the indicated radioisotope at room temperature for 15 minutes, and then at $37^{\circ} \mathrm{C}$ for 15 minutes, and 1 hour in fresh medium. To compensate for potential radioisotope-specific artifacts, each cell population was split into two parts, and one half was labeled with ${ }^{51} \mathrm{Cr}$, and the other half with ${ }^{111} \mathrm{In}$, and we carried out the same experiments by using different combination of radioisotopes. Cell suspensions containing equal numbers of radioisotope-labeled $C x c r 4^{+/+} / L c k-C r e T$ cells and Cxcr $\Psi^{f l o x} / f l o x / L c k-C r e T$ cells were prepared, and $0.2 \mathrm{ml}$ of $2 \times 10^{7}$ cells $/ \mathrm{ml}$ cell suspensions was injected to the recipient mice. Twenty hours after injection, LNs and digital joints were harvested, and the radioactivities were measured by using a $\gamma$-counter (Wallac, Turku, Finland). Radioactivities of ${ }^{51} \mathrm{Cr}$ and ${ }^{111}$ In were measured separately, and cell accumulation was estimated by the radioisotope counts. Cell migration was not affected by the radioisotopes used for the labeling.

\section{Flow cytometry}

Single-cell suspensions were prepared from LNs, spleens, thymus glands, and joints, and stained with FITC-, PE-, PerCP-, APC-, or biotin-conjugated antibodies. Biotinylated antibodies were visualized with PE- or APCconjugated streptavidin (BD Biosciences). To prepare single-cell suspensions from joints, joints were collected and digested with 200 units/ml of collagenase (type VIII, Sigma) and hyaluronidase $(1.5 \mathrm{ng} / \mathrm{ml})$ in FCS-supplemented RPMI1640 medium for 1.5 hour at $37^{\circ} \mathrm{C}$ with gentle mixing. Then cells were filtered with cell strainers (Falcon) and stained. Stained cells were analyzed with FACSCalibur and FlowJo software. Antibodies to CXCR4 (BD Pharmingen), CD44 (eBioscience), CCR6 (R\&D Systems), CD62L (BD Pharmingen), CD4 (BD Pharmingen), and $\mathrm{CD} 8$ (BD Pharmingen) were used.

\section{Immunohistochemistry}

For immunohistochemical analysis, hindlimbs from normal mice and CIA-affected mice were embedded in CMC gel with hexane, and cryostat sections $(5 \mu \mathrm{m})$ were generated. The sections were fixed in cold acetone for 5 minutes and blocked with $2 \%$ bovine serum albumin (Sigma) in PBS with 0.05\% Tween 20. Antibodies used were as follows; biotinylated rat anti-murine CXCR4 (BD Pharmingen), rabbit anti-murine CD3 (Abcam, Ab16044), biotinylated donkey anti-rat IgG (Jackson) to amplify the signal from CXCR4, streptavidin FITC (BD Pharmingen), and Cy3 goat anti-rabbit IgG (Jackson). Nuclei were stained with Hoechst 33258 (WAKO). The slides were visualized on a Nikon A1RsiTiE confocal microscope operated by NIS-Elements software (see also Additional file 1).

\section{Statistics}

Student's $t$-test and the $\chi^{2}$-test were used for the statistical evaluation.

\section{Results}

T cell-specific Cxcr4-deficient mice were generated by crossing Lck-Cre transgenic mice with Cxcr ${ }^{\text {flox/flox }}$ mice To investigate the roles of CXCR4 in T cells, we generated $\mathrm{T}$ cell-specific conditional gene-targeted mice, as 
described in Materials and methods. Mice harboring lox $P$ sites flanking the second exon of Cxcr4 gene (Cxcr $4^{\text {flox/flox }}$ mice) were generated by homologous recombination (Figure 1a) and crossed with a Lck-Cre transgenic mouse [18]. Deletion of the Cxcr4 gene and CXCR4 protein in the thymus of Cxcr $4^{\text {flox/flox }} / \mathrm{Lck}$-Cre mice was confirmed (Additional file 2a, b). KO mice were born in the mendelian ratio, and no gross phenotypic abnormalities were observed. Cre recombinase was activated from the DN3 stage of thymic T-cell development in Cxcr $4^{\text {flox } / f l o x} / \mathrm{Lck}$-Cre mice (Additional file 2c). No significant abnormalities in T-cell number and population in LNs and spleen were found in Cxcrfflox/ flox/Lck-Cre mice, although thymocytes were significantly reduced (Additional file 2d), indicating that CXCR4 deficiency does not affect peripheral T-cell development.

\section{The development of $\mathrm{ClA}$ is significantly impaired in Cxcr4 $4^{\text {flox/flox } / \text { Lck-Cre mice }}$}

We examined the effect of T cell-specific Cxcr4 deficiency in the development of CIA. The incidence of the CIA was significantly more decreased in $C x c r 4^{\text {flox/flox } /}$ Lck-Cre mice than in Cxcr4 $4^{+/+}$mice, Cxcr $4^{\text {flox/flox }}$ mice, or $\mathrm{Cxcr}^{+/+} /$Lck-Cre mice (Figure 1b). Conversely, no significant difference was found in the severity score of the arthritic mice between Cxcr fflox/flox $/$ Lck-Cre mice and $\mathrm{Cxcr} 4^{+/+} /$Lck-Cre mice (Figure 1c). In the histologic analysis, affected joints of both control mice and Cxcr $4^{\text {flox/flox }} /$ Lck-Cremice showed typical features of arthritis, characterized by marked perivascular infiltration of inflammatory cells, synovial hyperplasia, and bone erosion (Figure 1d). In the joints of nonarthritic Cxcr $4^{\text {flox/flox } / L c k-C r e ~ m i c e, ~ t h e s e ~ a r t h r i t i c ~ p a t h o l o g i e s ~}$ were not detected. These observations suggest that CXCR4 in T cells plays an important role in the development of arthritis.

\section{Thymocytes and LN T cells migrate toward SDF-1 in a CXCR4-dependent manner}

To elucidate functional roles of CXCR4 in T cells, we examined T-cell chemotaxis to SDF-1 by using chemotaxis chambers. Thymocytes from $C x c r 4^{+/+} / L c k$-Cre mice efficiently migrated to SDF-1 (Figure 2a). In contrast, migration of Cxcr $4^{f l o x / f l o x} / L c k$-Cre mouse-derived thymocytes was greatly reduced. Likewise, T cells purified from LNs of wild-type mice efficiently migrated toward SDF-1, whereas cells from Cxcr $4^{\text {flox } / f l o x} / L c k$-Cre mice migrated less efficiently (Figure 2b), indicating that SDF-1-CXCR4dependent chemotaxis is functional in T cells, similarly to hematopoietic cells and mature B cells $[25,26]$.

\section{Humoral and cellular responses to IIC are normal in Cxcr4 $4^{\text {flox/flox} / L c k-C r e ~ m i c e ~}$}

As antibody production and cellular response to IIC are important for the development of CIA [5], we next analyzed the antibody titer in sera and the proliferative response of LN cells to IIC. Although IIC-specific IgG in the serum of Cxcr $4^{\text {flox/flox }} /$ Lck-Cre mice tended to
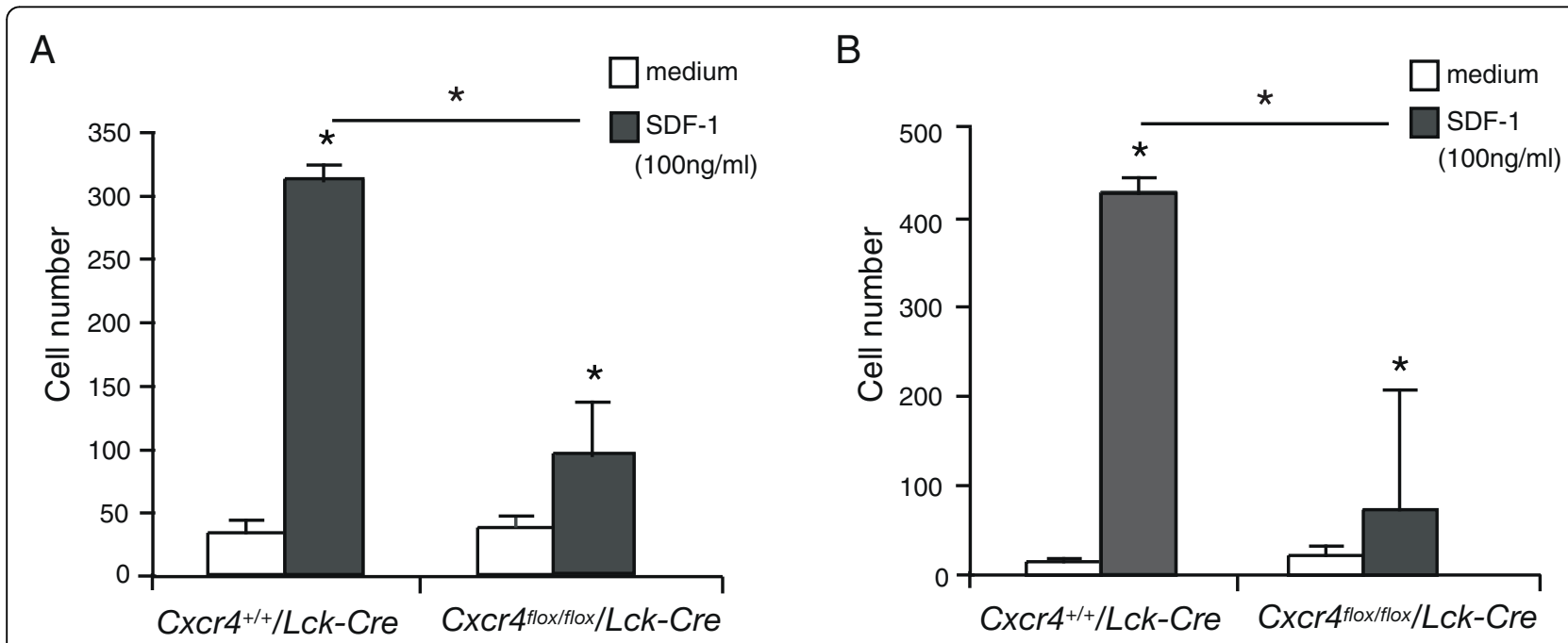

Figure 2 Cxcr $4^{\text {flox/flox }} /$ Lck-Cremouse-derived T cells show impaired chemotaxis toward SDF-1. The chemotaxis toward SDF-1 of T cells from $\mathrm{CxCr} 4^{+/+} /$Lck-Cre mice or $\mathrm{CxCr} 4^{\text {floxflox }} /$ Lck-Cre were assessed with in vitro chemotaxis assays, as described in Materials and methods. Representative results in at least two independent experiments are shown. (a) Chemotaxis of thymocytes to SDF-1 or medium was compared between Cxcr4 ${ }^{+/+} /$Lck-Cre mice and Cxcr $4^{f l o x}$ fllox $/ L c k$-Cre mice. ${ }^{*} P<0.05$, by Student's $t$-test. (b) Chemotaxis of purified T cells from LNs was assessed. Results are shown as mean \pm SD of triplicate determinations and are representative of at least two similar experiments. ${ }^{*} P<0.05$, by Student's $t$-test Open columns indicate numbers of cells migrated into the chambers filled with medium only, and black columns, into the chambers with the medium supplemented with SDF-1 $(100 \mathrm{ng} / \mathrm{ml})$. 
decrease at day 60 of immunization, no significant differences between the control mice were found at days 7 and 60 (Figure 3a and Additional file 3a). In addition, no significant difference of $L N$ cells was found in the proliferative response to anti-IgM antibodies (Additional file $3 \mathrm{~b}$ ). These data indicate that $\mathrm{B}$-cell function is normal in Cxcr $4^{\text {flox/flox }} /$ Lck-Cre mice. To examine the cellular response to IIC, Cxcr $4^{\text {flox/flox }} /$ Lck-Cre mice and Cxcr4 ${ }^{+/+} /$Lck-Cre mice were immunized with IIC with CFA, and LN cells from these mice were restimulated with IIC in vitro. The proliferative response to IIC was normal in Cxcr $4^{\text {flox/flox }} /$ Lck-Cre mouse-derived LN cells (Figure $3 \mathrm{~b}$ ), and levels of IL-17 and IFN- $\gamma$ in the culture supernatant were also normal (left columns in Figure 3c and $3 \mathrm{~d}$ ). To confirm these results, we stimulated LN cells from immunized mice with anti-CD3 antibody instead of IIC in the same experimental settings and detected normal levels of IL-17 and IFN- $\gamma$ in the culture supernatant (right columns in Figure $3 \mathrm{c}$ and $3 \mathrm{~d}$ ) in

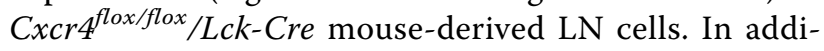
tion, the expression levels of CD62L, a naïve T-cell marker, and CD25, a T cell-activation marker, and CCR6 for Th17 marker, were similar between Cxcr $\Psi^{f l o x} /$ flox $/ L c k$ Cre mice and $C x c r 4^{+/+} / L c k-C r e$ mice (Figure $3 e$ and Additional file 4). As it was reported that pretreatment of T cells with SDF-1 enhances TCR-induced proliferative response $[27,28]$, we examined the effect of SDF-1 treatment on the IIC-induced T-cell proliferation. However, no significant enhancement in T-cell proliferative response was observed in our experimental conditions (Additional file 5).

\section{CXCR4-expressing $T$ cells are increased in the draining LNs of arthritic mice}

Because CXCR4 was not involved in the humoral and cellular responses to IIC, we hypothesized that the CXCR4-mediated chemotaxis of $\mathrm{T}$ cells is involved in the development of CIA. To verify this possibility, we investigated the proportion of the CXCR4-expressing $\mathrm{T}$ cells in the LNs and the joints (Figure 4a-c, Figure 5, and Figure $6 \mathrm{a}-\mathrm{c}$ ). DBA/1J mice were immunized with IIC/CFA to induce arthritis, and the expression of CXCR4 was determined with FACS analysis. In cells from the draining LNs, a peak-shift of the intensity was observed in arthritic mice compared with nonarthritic mice, indicating that CXCR4 was induced in arthritic mice (Figure 4a, b, and Additional file 6). Furthermore, cryostat sections of LNs stained with anti-CD3 and antiCXCR4 antibodies revealed that the number of CXCR4expressing $\mathrm{T}$ cells was increased in the arthritic mice compared with nonarthritic mice (Figure 4c, summarized in Figure 6c).

The expression of CXCR4 also tended to increase in nonarthritic mice after IIC/CFA immunization, although the increase was not statistically significant (Figure 4a, b). The expression of CXCR4 increased in mice immunized with CFA only, but LN cells from these mice did not respond to stimulation by IIC or develop arthritis (Additional file 7). The expression of CXCR4 was significantly increased in $C D 62 \mathrm{~L}^{\text {low }}$ population, indicating that CXCR4 expression was induced in activated $\mathrm{T}$ cells (Figure 4d). Furthermore, we examined the effect of anti-CD3 stimulation of LN cells on the CXCR4 expression in T cells. As shown in Figure 4e, CD44 $4^{\text {high }} \mathrm{T}$-cell population contained a higher proportion of CXCR4 $4^{\text {high }}$ cells, and the percentage of CXCR $4^{\text {high }}$ cells in CD $44^{\text {high }}$ T-cell population was higher in arthritic mice, consistent with the results in Figure 4d. These observations indicate that immune activation of $\mathrm{T}$ cells induces CXCR4 expression.

\section{T-cell accumulation in arthritic joints is dependent on CXCR4 expression in T cells}

Next, we examined expression of CXCR4 in arthritic joints. Although $\mathrm{CD}^{+} \mathrm{T}$ cells were found in both nonarthritic and arthritic joints, the number of $\mathrm{T}$ cells was significantly increased in arthritic joints, and most of the $\mathrm{T}$ cells expressed CXCR4 (Figures 5 and 6a). The expression of the Cxcl12 was also augmented in arthritic joints (Figure 6b). Furthermore, we found that the $\mathrm{CXCR}^{+}$cell population in total $\mathrm{T}$ cells was much higher in the inflammatory sites of affected joints than in LNs (Figure 6c), indicating that $\mathrm{CXCR} 4^{+}$cells accumulated in the inflammatory sites. It is remarkable that some $\mathrm{CD}^{+} \mathrm{T}$ cells were closely apposed to SDF-1-positive cells in arthritic joints (Additional file 8), consistent with the idea that SDF-1 attracted these CXCR4-expressing cells.

To show whether T-cell accumulation in the joints during the development of CIA depends on the CXCR4/ SDF-1 system, T cells from Cxcr $4^{\text {flox } / \text { flox }} /$ Lck-Cre mice and $C x c r 4^{+/+} / L c k$-Cre mice were labeled with radioisotopes and injected into IIC/CFA-immunized mice, and T-cell migration into joints was analyzed (Figure 6d). Recovery of radioisotope-labeled $\mathrm{T}$ cells in affected joints was significantly decreased by the deficiency of CXCR4. These data clearly indicate that activated $T$ cells were accumulated in inflamed joints in a CXCR4dependent manner.

\section{Discussion}

CIA is a model for autoimmune arthritis characterized by autoantibody production and massive infiltration of effector cells to joints $[29,30]$. However, immunization with native murine IIC shows a much lower incidence of arthritis in DBA/1J mice [31], and immunization with heterologous IIC, such as chicken or bovine, shows a much higher incidence in CIA. A peptide from chicken 
A

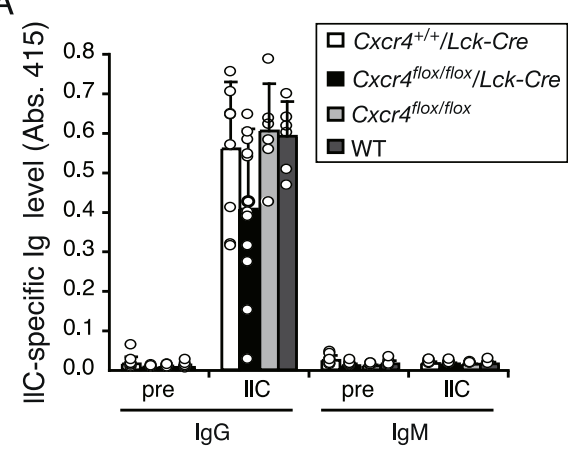

C
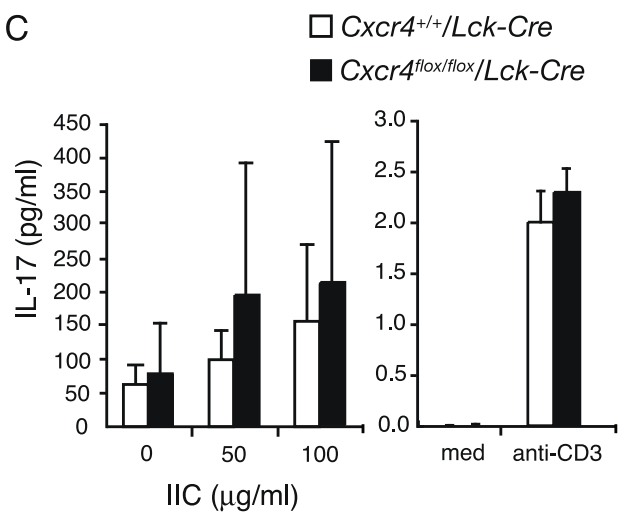

$\mathrm{E}$

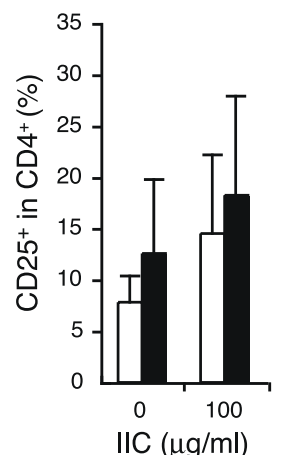

B

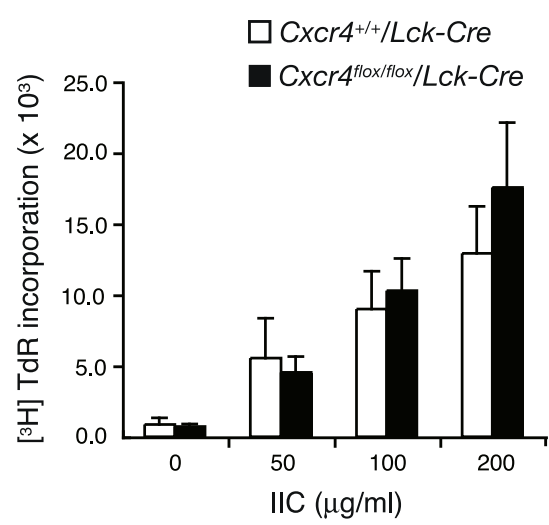

$\mathrm{D}$
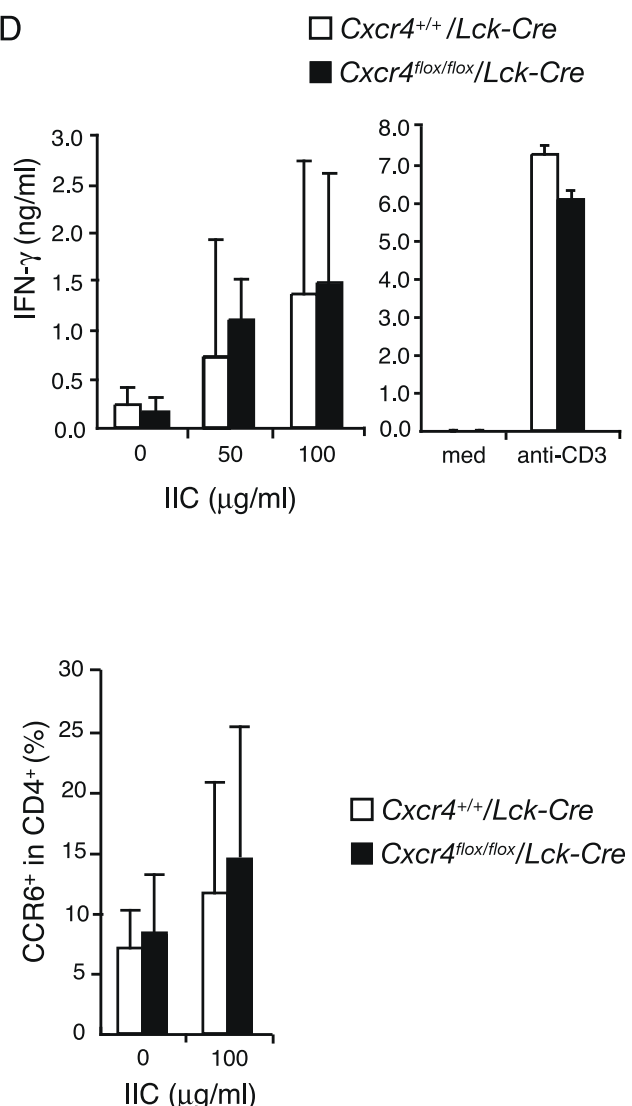

$\square \mathrm{CxCr}^{+++} / \mathrm{Lck}-\mathrm{Cre}$

- Cxcr4 $4^{\text {flox/flox } / L c k-C r e}$

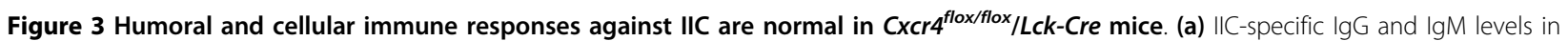
the serum were determined with ELISA 60 days after immunization with IIC/CFA. Each circle represents an individual mouse, and averages and SDs are shown. CXCr4 ${ }^{+/+} / L C k$-Cre mice: open columns $(n=9) ; C x C r 4^{\text {floxflox}} / L C k$-Cre mice: closed columns $(n=11) ; C x C r 4^{\text {floxfllox }}$ mice: light gray columns $(n=6)$; and WT DBA/1J mice: dark gray columns $(n=6)$. Data are representative of two independent experiments. (b) T-cell recall proliferative response toward IIC was assessed 1 week after immunization with IIC/CFA. LN cells from CXCr4 ${ }^{+/+} / L C k$-Cre or CXCrfflox/flox/LCk-Cre mice were harvested and cultured in the presence or absence of 50 , and $100,200 \mu \mathrm{g} / \mathrm{ml}$ of denatured $\| \mathrm{C}$ at $37^{\circ} \mathrm{C}$ for 72 hours, and T-cell proliferation was assessed with $\left[{ }^{3} \mathrm{H}\right]$-thymidine incorporation by using three wells for each mouse. The average and SD of four mice are shown for each column. Representative data from three independent experiments are shown. IL-17 (c) and IFN- $\gamma$ (d) levels in the culture supernatants were measured with ELISA. Triplicate (proliferation, IFN- $\gamma$ ) or duplicate (IL-17) wells were used for each mouse, and averages and SDs of three mice are shown. Data are representative of at least two independent experiments. In the right columns, IL-17 (c) and IFN- $\gamma$ (d) levels in cultures of LN cells from two immunized mice after stimulation with $1 \mu \mathrm{g} / \mathrm{ml}$ of anti-CD3 antibody at $37^{\circ} \mathrm{C}$ for 72 hours are shown. Averages and SDs of triplicate wells are shown, and data are representative of two independent experiments. (e) LN cells from immunized mice were pooled and stimulated with or without $100 \mu \mathrm{g} / \mathrm{ml}$ of $\| \mathrm{C}$ for 72 hours. The proportion of CD25 $5^{+}, \mathrm{CD}_{2} \mathrm{~L}^{-}$, and CCR6 ${ }^{+}$cells in $\mathrm{CD}^{+}$cells was analyzed with FACS. Data from three independent experiments were combined, and averages and SDs are shown. 


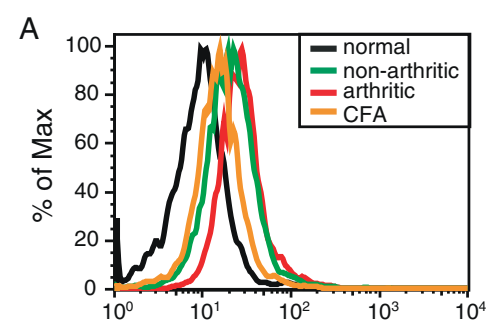

C
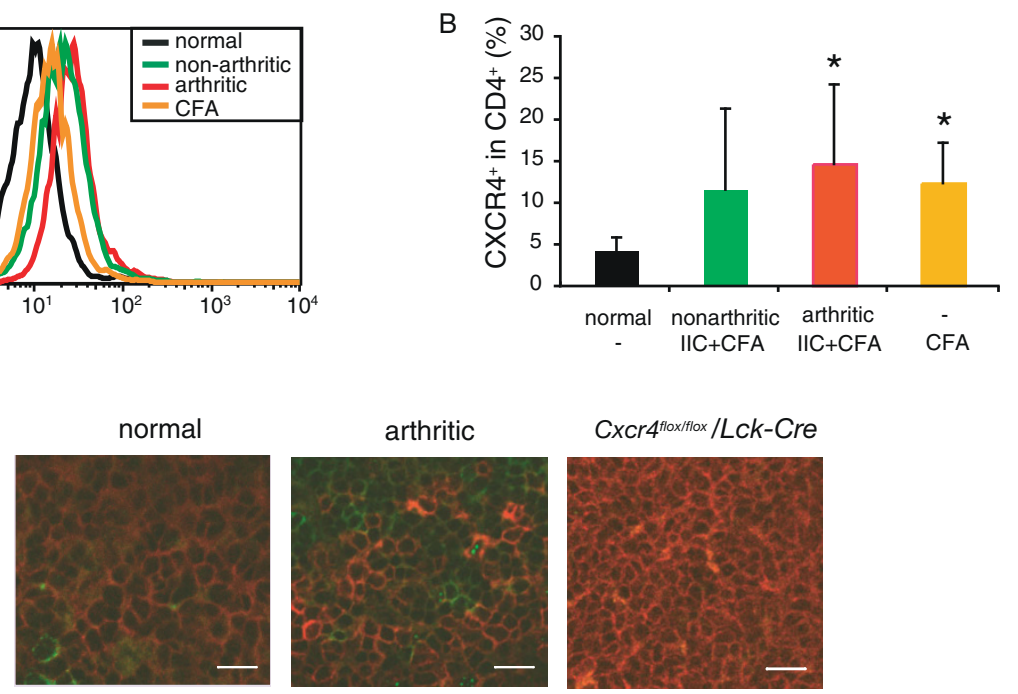

D
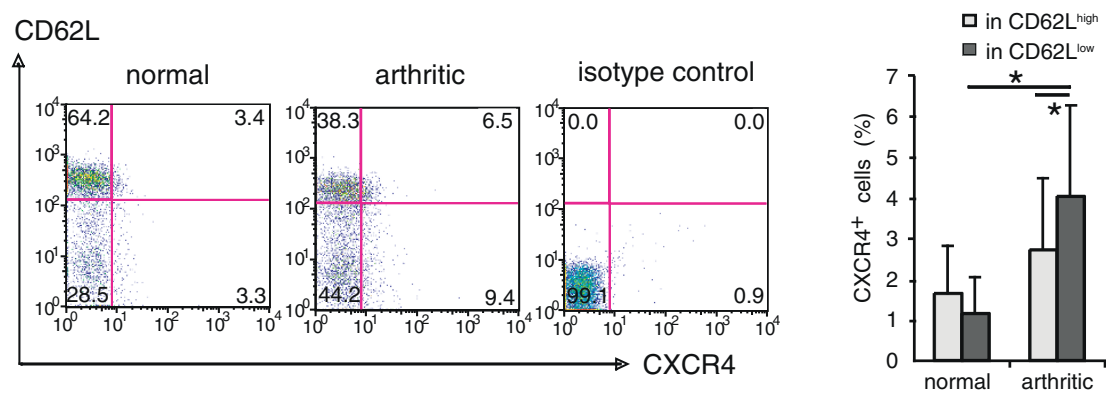

$\mathrm{E}$

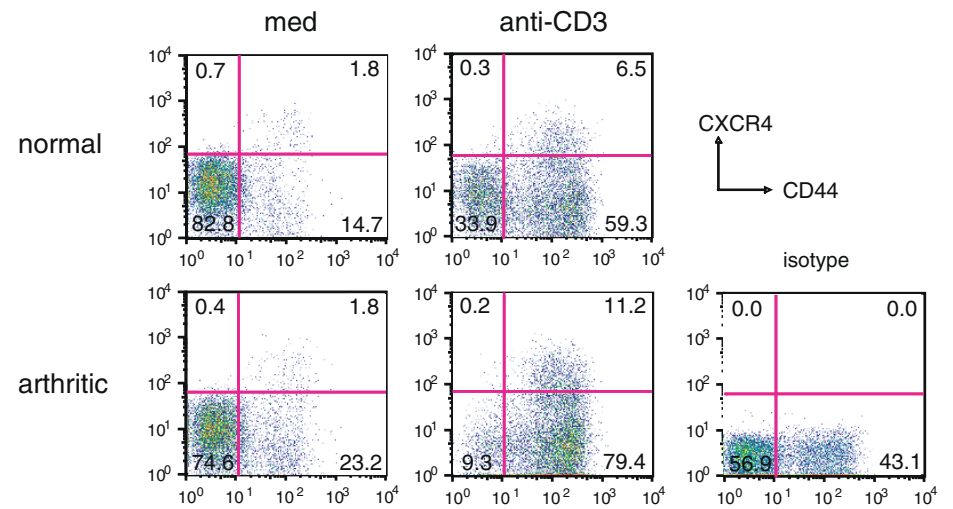

Figure 4 CXCR4-expressing T cells are increased in LNs during the development of CIA. DBA/1J mice were immunized with IIC and CFA, or CFA only, on day 0 and day 21. At day 30, arthritis development was determined, and LN cells were collected. (a) CXCR4 expression was analyzed with flow cytometry in CD4 ${ }^{+} \mathrm{T}$ cells from IIC and CFA-immunized mice (arthritic and nonarthritic), CFA-immunized mice (nonarthritic), and normal nonimmunized DBA/1J mice. Representative data from two similar experiments are presented. (b) Proportion of CXCR4 ${ }^{+}$cells in CD4 ${ }^{+}$cells from normal DBA/1J mice without immunization $(n=3)$, IIC and CFA-immunized nonarthritic $(n=4)$ and arthritic $(n=7)$ and CFAimmunized nonarthritic $(n=7)$ mice are shown. Data from two similar experiments were combined. ${ }^{*} P<0.05$ by Student's $t$ test. (c) The expression of CXCR4 was analyzed with immunohistochemistry. CXCR4 was labeled with green fluorescence, and CD3 was labeled with red fluorescence. An increased number of CXCR4-expressing T cells is found in LNs from arthritic mice than those from normal mice. Representative figures among three sections from normal mice and three sections from arthritic mice are presented. White bar represents $20 \mu \mathrm{m}$. (d) CXCR4 and $\mathrm{CD} 62 \mathrm{~L}$ coexpression was analyzed in $\mathrm{CD}^{+}$cells. Representative plots gated on $\mathrm{CD}^{+}$cells are presented, and all the data from 10 normal nonimmunized mice and 11 IIC/CFA-immunized arthritic mice are summarized on the right. Averages and SDs are shown. ${ }^{*} P<0.05$ by Student's $t$ test. (e) LN cells from two nonimmunized normal or IIC/CFA-immunized arthritic mice were pooled and cultured in the absence or presence of $1 \mu \mathrm{g} / \mathrm{ml}$ of anti-CD3 antibody for 72 hours, and CXCR4 and CD44 expression was analyzed in CD4 ${ }^{+}$cells. Representative plots gated on CD4 cells from two independent experiments are shown. 

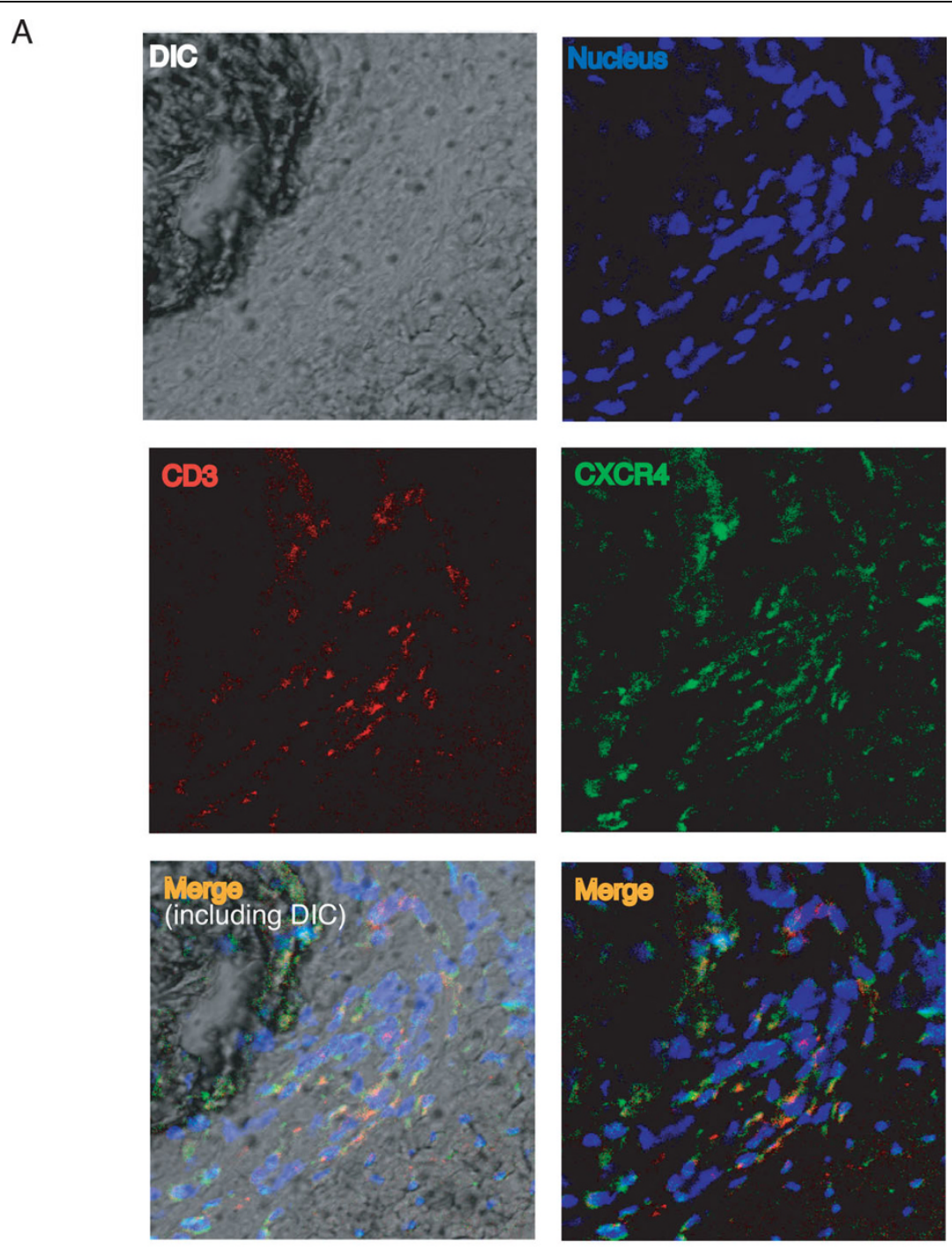

B

\section{CXCR4} anti-CXCR4 antibody
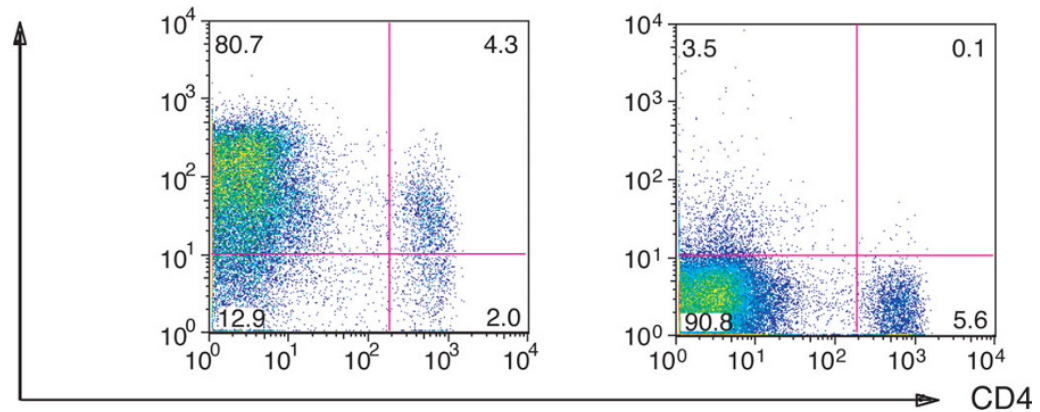

Figure 5 CXCR4 is expressed in most of synovial T cells from arthritic mice. Mice were induced CIA and CXCR4 expression in the affected joints was analyzed by immunohistochemistry. Cryostat sections of the limb joints from arthritic mice or normal mice were generated and stained with anti-CD3 and anti-CXCR4 antibodies. (a) Representative data among sections from three normal mice and three arthritic mice are shown. Data are summarized in Figure 6c. (b) CXCR4 expression on T cells was analyzed with FACS. As described in Materials and methods, affected limbs from CIA-developed mice were treated with hyaluronidase and collagenase to obtain single-cell suspensions, and stained with anti-CD4 and anti-CXCR4 antibodies. Representative data among three similar experiments are shown. 


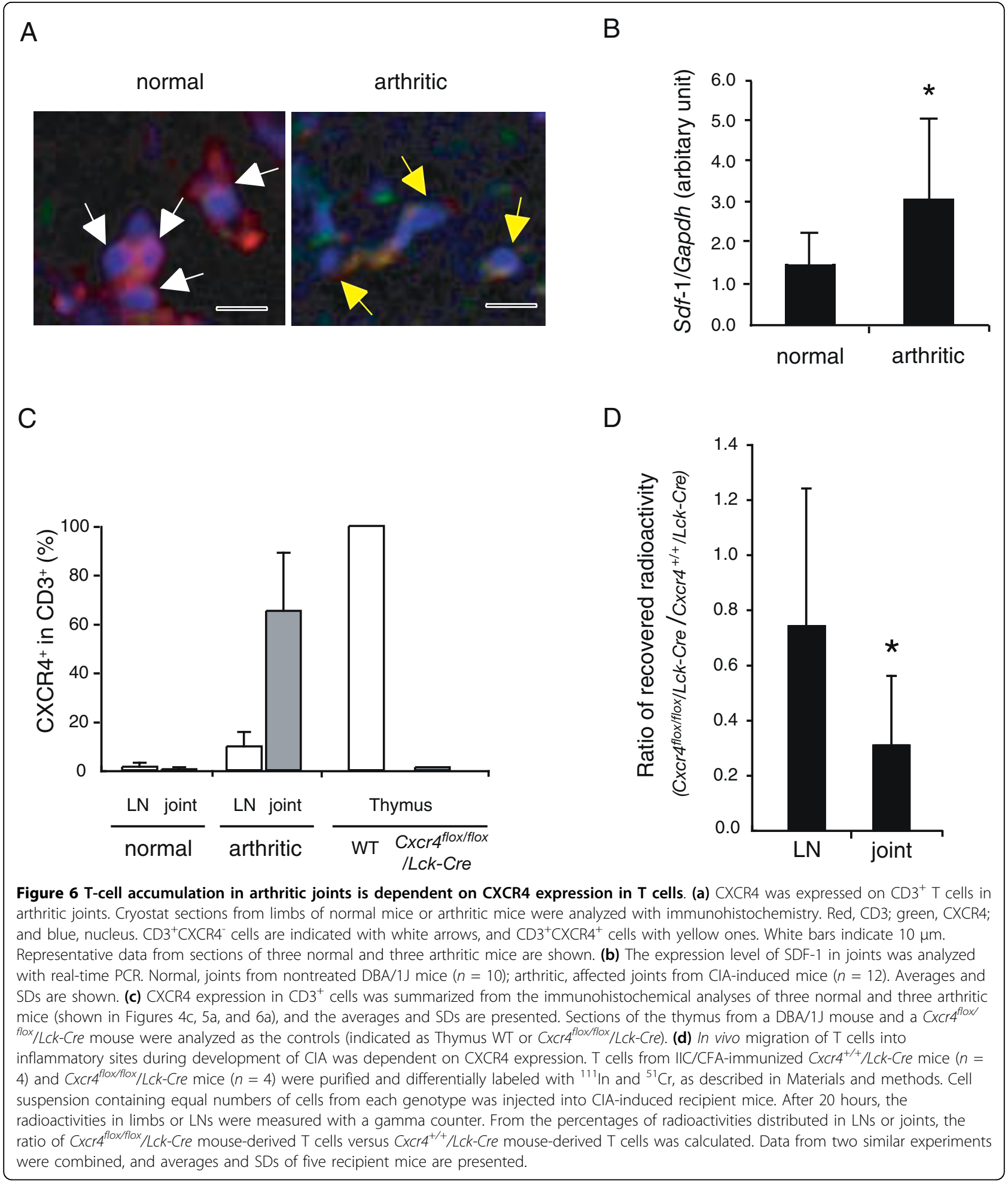

IIC (aa. 256 to 270) is known as a major immunodominant epitope $[31,32]$, and the difference between heterologous IIC and murine IIC, which is important in the development of arthritis, is the presence of a glutamic acid at position 266 in chicken IIC. The T-cell response to this epitope is suggested to break tolerance to induce responses toward homologous epitopes in murine IIC. Bovine IIC (256-270)-specific T cells also crossreact with mouse IIC [32]. Interestingly, human IIC also shares this immunodominant epitope, because chicken 
IIC-reactive T-cell hybridoma responds to human IIC [33]. Furthermore, anti-human IIC antibodies purified from RA patients' sera react with chick and bovine IIC [34]. Thus, it is believed that chicken IIC-induced CIA is a good model for human RA.

It was reported that the proportion of CXCR4-expressing memory $\mathrm{T}$ cells and the expression of the ligand, SDF-1, are increased in RA synovium, suggesting that the SDF-1-CXCR4 system is involved in the pathogenesis of RA [11,12,35]. However, the precise functional roles of this molecule in $\mathrm{T}$ cells remains to be elucidated. In this study, we showed that the incidence, but not the severity, of CIA was significantly decreased in Cxcr $4^{\text {flox/flox }} /$ Lck-Cre mice, indicating that CXCR4 expression in $\mathrm{T}$ cells is important for the development of CIA. CXCR4 expression was enhanced in activated/ memory $\mathrm{T}$ cells, and CXCR4-deficient $\mathrm{T}$ cells were defective in SDF-1-induced chemotaxis. Both CXCR4 expression in $\mathrm{T}$ cells and SDF-1 expression in the affected joints was augmented during the development of CIA, and CXCR4-expressing $\mathrm{T}$ cells were accumulated in the inflammatory sites where SDF-1 was strongly expressed. Importantly, on induction of CIA, the proportion of CXCR4-expressing $\mathrm{T}$ cells was increased in the inflammatory sites compared with that in the draining LNs, and infiltrated T cells were closely apposed with SDF-1-expressing cells. Although immunization with CFA without IIC enhanced CXCR4 expression in $\mathrm{T}$ cells, this could not induce arthritis, suggesting that CXCR4 expression in IIC-specific T cells is important for the induction of arthritis. Thus, the SDF-1-CXCR4 system in T cells is important to recruit memory $\mathrm{T}$ cells to the site of inflammation, rather than to the LNs. Because cytokines such as IL-15 and TGF- $\beta$ can induce and/or sustain the expression of CXCR4 in $\mathrm{T}$ cells $[12,36]$, cytokines from activated LN cells in IICimmunized mice may enhance CXCR4 expression. Consistent with this notion, we showed that the antibody production and T-cell response against IIC were normal in $C x c r 4^{f l o x / f l o x} / L c k$-Cre mice.

We suggest that CXCR4 expression in T cells plays an important role in mediating $\mathrm{T}$-cell recruitment to inflamed sites. However, the importance of $\mathrm{T}$ cells, especially the recruitment of $\mathrm{T}$ cells to inflamed sites in the development of CIA, has been ignored for a long time. This is because adoptive transfer experiments suggest the importance of antibodies, but not $\mathrm{T}$ cells, in the development of arthritis [29,31]. CIA can be transferred by serum from arthritic mice, whereas $\mathrm{T}$-cell transfer from arthritic mice to normal or lymphopenic mice cannot induce the development of arthritis [29,31]. However, it was reported that transfer of splenocytes from arthritic mice to SCID mice can induce arthritis [37]. In this experiment, the incidence of arthritis was greatly decreased when either T cells or B cells were depleted from the splenocytes. These observations suggest that $\mathrm{T}$ cells are involved in the development of arthritis, although $\mathrm{T}$ cells alone cannot induce arthritis. Furthermore, the involvement of $\mathrm{T}$ cells is reported in a collagen-antibody-induced arthritis (CAIA) model, in which arthritis is induced by the administration of collagen-specific antibodies [38]. This model has been considered to be independent of $\mathrm{T}$ cells, because $\mathrm{T}$ celldeficient mice were susceptible to CAIA [39]. However, injection of collagen-specific T cells to CAIA-induced mice prolonged the disease [39], and T-cell suppression by CTLA-4 Ig treatment [40] or CTLA-4 Ig and cyclosporine treatment [41] in a later phase of CAIA suppressed the severity of arthritis, indicating that $T$ cells play a role in CAIA as an amplifier. Accordingly, the following pathogenic processes are suggested. On production or administration of antibodies specific to IIC, these antibodies may activate mast cells by forming complexes with complements on cartilage IIC in joints, leading to the secretion of inflammatory cytokines and chemokines, including IL-1, similar to that reported in $\mathrm{K} / \mathrm{BxN}$ arthritic mice [42]. These inflammatory mediators may activate synovial cells to recruit effector $\mathrm{T}$ cells, which can secrete various inflammatory mediators on activation with endogenous IIC, resulting in the amplification of inflammation. Our results indicate that CXCR4-SDF-1 interaction plays an important role in recruiting effector $\mathrm{T}$ cells into inflamed sites.

Although it was reported that CXCR4 signaling enhances T-cell activation and proliferation in a synergistic manner with TCR signaling $[10,27,28,43]$, the proliferative response of LN cells from IIC-immunized Cxcr $4^{\text {flox/flox } / L c k-C r e}$ mice was normal on stimulation with IIC, and the cytokine production from these cells was also normal. We also did not detect any effects of SDF-1 on the proliferative response of IIC-immunized T cells to IIC stimulation. This apparent discrepancy might be caused by the difference of the experimental conditions; anti-CD3 antibodies were used to stimulate $\mathrm{T}$ cells in the previous reports $[10,27,28,43]$, whereas whole LN cells, including antigen-presenting cells, were activated with natural antigens in our experiments. Weak costimulatory activity of CXCR4 may be masked by the strong costimulatory signaling from the antigenpresenting cells.

Recently, it was reported that CXCR4 is involved in the $\beta$-selection during thymic T-cell development in $\mathrm{T}$ cell-specific Cxcr4-deficient mice [44]. In contrast to this report, no significant abnormality was detected in the T-cell population and cell number in lymph nodes and the spleen between Cxcr $4^{f l o x / f l o x} / L c k$-Cre mice and $\mathrm{Cxcr} 4^{+/+} /$Lck-Cre mice (Additional file $2 \mathrm{~d}$ and $2 \mathrm{e}$ ), although in the thymus, the $\mathrm{T}$-cell number was 
decreased without affecting the $\mathrm{CD} 4^{+}$or $\mathrm{CD} 8^{+}$cell content in Cxcr $\Psi^{f l o x} / f l o x / L c k$-Cre mice. We think this difference from the previous report was caused by the difference of the $L c k$-Cre transgenic mouse line we used. We found that, in our Cxcr $\Psi^{\text {flox/flox }} / L c k$-Cre mouse thymus, CXCR4 expression still remained in the DN3 stage (Additional file 2c), suggesting that this remaining CXCR4 rescued potential defects in the thymic $\beta$-selection.

Cxcr4-deficient mice developed arthritis with very low incidence (two of 11), but the severity of arthritis was comparable to that of control mice (Figure 1b-d). These data suggest that CXCR4 is required for the initiation of inflammation by recruiting IIC-specific $\mathrm{T}$ cells into inflammatory sites. However, IIC-specific effector T cells would migrate into joints by the action of other chemokines or even by chance, without involvement of CXCR4, although the frequency may be low. Then these $\mathrm{T}$ cells are activated with IIC in the joints and produce various cytokines and chemokines, which recruit or activate other inflammatory cells, such as neutrophils. Therefore, once inflammation starts, other chemokines and cytokines may play more important roles than CXCR4, or other chemokines may substitute for the role of CXCR4 in the later stages of inflammation, resulting in the development of arthritis in Cxcr $4^{f l o x} /$ flox $/ L c k$-Cre mice. In support for this contention, we showed that most of the inflammatory cells infiltrated in inflammatory sites were neutrophils, and only a part of them were $\mathrm{CD}^{+}{ }^{+} \mathrm{T}$ cells (Figure 5). Furthermore, we showed that CCR6, which is important for the development of arthritis in SKG mice by enhancing the migration of Th17 cells, was expressed normally in Cxcr4-deficient T cells (Figure 3e). The expression of CD62L, which is important for $\mathrm{T}$-cell migration to peripheral tissues, was also normal (Figure 3e).

On induction of CIA, the expression of SDF-1 was augmented. Regarding SDF-1, it was reported that inflammatory cytokines, such as IL-17 [45] and IL-18 [46], can induce production of this molecule by fibroblast-like synoviocytes and stromal cells in the RA synovium. Conversely, CXCR4 is induced by TGF- $\beta$ and IL15 [36]. Thus, the cytokine production associated with the immune response against IIC may activate the expression of these molecules, resulting in trapping of activated $\mathrm{T}$ cells and recruitment of new $\mathrm{T}$ cells to the inflammatory sites. Because SDF-1-CXCR4 system is also active in B cells to activate and to migrate [47], in osteoclasts to produce MMP-9 [48], in chondrocytes to produce MMP-3 [49], in endothelium to induce angiogenesis [50], and in Th1 cells to migrate into synovial tissues [35], this system may play very important roles in a multiple ways in the development of RA. Therefore, these findings highlight the SDF-1-CXCR4 system as a good target for the treatment of RA.

\section{Conclusions}

We showed that CXCR4 expressed in T cells plays an important role in the development of CIA by recruiting activated/memory $\mathrm{T}$ cells into the inflammatory sites.

\section{Additional material}

Additional file 1: Supplemental Methods. Materials and methods that were used in supplemental figures are described in Additional file 1.

Additional file 2: Generation of T cell-specific CXCR4-deficient mice. (a) CxCr4 gene in the thymus. CxCr4 $4^{\text {flox/flox}} / \mathrm{LCk}-\mathrm{Cre}$, CxCr4 $4^{\text {flox/flox }}$, and wildtype DBA/1J mice was analyzed by Southern blot analysis, as described in Supplemental Methods in Additional File 1. In brief, genomic DNA from thymocytes was digested with $\mathrm{Scal} / \mathrm{Xbal}$, and hybridized with $0.8 \mathrm{~kb}$ Scal fragment as a $5^{\prime}$ probe at $42^{\circ} \mathrm{C}$ for overnight. Deleted allele, $6.1 \mathrm{~kb}$

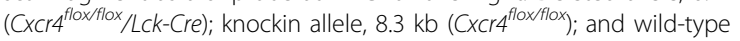
allele, $10.1 \mathrm{~kb}(\mathrm{WT})$. (b) CXCR4 expression in thymocytes was assessed with FACS. (c) Thymocytes were stained with antibodies against CD4, CD8, CD25, CD44, and CXCR4, and DN3 (CD25 $\left.{ }^{+} \mathrm{CD} 44^{-} \mathrm{CD}^{-} \mathrm{CD} 8^{-}\right)$, DN4 $\left(\mathrm{CD} 25^{-} \mathrm{CD} 44^{-} \mathrm{CD} 4^{-} \mathrm{CD} 8^{-}\right)$, DP $\left(\mathrm{CD}^{+} \mathrm{CD}^{+}\right)$, and DN (CD4 $\left.4^{-} \mathrm{CD} 8^{-}\right)$cells were gated. CXCR4 expression was detected in DN3 and DN4 stages, although the intensity was somewhat decreased, and only a little CXCR4 expression was detected at the DP stage. Representative data from five $\mathrm{CxCr}^{+/+} / \mathrm{LCk}$-Cre mice and five CxCr4 flox/flox $/ \mathrm{LCk}$-Cre mice are shown. (d) Tcell numbers (left column) and populations (right column) in the thymus, LNs, and spleen were determined with flow cytometry. Means and SDs

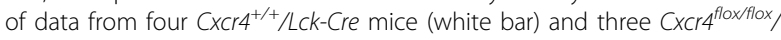
Lck-Cre mice (black bar) are shown. ${ }^{*} P<0.05$, with Student's $t$ test. (e) The proportion of $\mathrm{CD}^{+} \mathrm{T}$ cells in LNs in normal mice and IIC-immunized mice (day 7) were analyzed with flow cytometry. Means and SDs of data from three $\mathrm{CxCr}^{+/+} /$Lck-Cre mice (white bar) and three $C x \mathrm{Cr} 4^{\text {flox/flox }} / \mathrm{LCk}$-Cre mice (black bar), which were immunized 7 days before, are presented. Data are representative of more than two independent experiments.

Additional file 3: B-cell response is normal in Cxcr4 $4^{\text {flox/flox }} / \mathrm{Lck}$-Cre mice. (a) $I C$-specific IgG antibody titer in sera was measured 7 days after IIC immunization with ELISA. Each circle represents one mouse. (b) Proliferative response of $B$ cells was measured after stimulation with IgM. LN cells from IIC-immunized mice (four $\mathrm{CxCr}^{+/+} / \mathrm{LCk}$-Cre mice and four Cxcr4 flox/flox $/ L C k$-Cre mice) were stimulated with/without $1 \mu \mathrm{g} / \mathrm{ml}$ of antiIgM antibody for 3 days, and proliferative response was measured with $\left[{ }^{3} \mathrm{H}\right]$-thymidine incorporation for 6 hours.

Additional file 4: T cells from draining LNs are normally activated in Cxcr4 ${ }^{\text {flox/flox } / L c k-C r e ~ m i c e ~ a f t e r ~ I I C ~ i m m u n i z a t i o n . ~ L N ~ c e l l s ~ f r o m ~ I I C / ~}$ CFA-immunized mice were stimulated with or without $100 \mu \mathrm{g} / \mathrm{ml}$ of ICC at $37^{\circ} \mathrm{C}$ for 72 hours, and the expression of CD25, CD62L, and CCR6 on $\mathrm{CD}^{+}$cells was analyzed with FACS. Representative data from three independent experiments are shown, and all the data are summarized in Figure $3 e$.

Additional file 5: T-cell recall response against IIC is not enhanced by SDF-1. One week after intradermal immunization with chicken IIC/ CFA, LN cells collected from three DBA/1J mice were cultured in fresh medium for 3 hours and stimulated with SDF-1 $(100 \mathrm{ng} / \mathrm{ml})$ for 2.5 hours. Then these cells were cultured in the presence or absence of $50 \mu \mathrm{g} / \mathrm{ml}$ of denatured chicken IIC for 72 hours. Proliferative response was measured with $\left[{ }^{3} \mathrm{H}\right]$-thymidine incorporation in triplicates, and averages and SDs of triplicates are shown. Data are representative of two independent experiments.

Additional file 6: CXCR4 expression is elevated in LN T cells from arthritic mice. CXCR4 expression in draining LN CD4 ${ }^{+} \mathrm{T}$ cells from CIAinduced mice was examined with flow cytometry. (a) CXCR4 expression in CIA-induced arthritic DBA/1J mice (arthritic), or nontreated DBA/1 J (normal) mice. Representative data among five normal mice and nine arthritic mice are shown. (b) Statistical analysis of CXCR4 expression. Each circle represents an individual mouse, and averages and SDs are shown. ${ }^{*} P<0.05$, Student's $t$ test.

Additional file 7: Immunization with CFA without IIC cannot induce CIA. DBA/1J mice were immunized with IIC and CFA $(n=7)$, or CFA only 
$(n=4)$. (a) Incidence of CIA. (b) T-cell proliferative response against IIC stimulation. Draining LN cells were stimulated with IIC for 72 hours, and the proliferative response was measured with $\left.{ }^{3} \mathrm{H}\right]$-thymidine incorporation for 6 hours. Representative data from two similar experiments are shown.

Additional file 8: T cells are closely apposed to SDF-1-expressing cells in arthritic joints. The expression of SDF-1 and CD3 was assessed in arthritic joints with immunohistochemistry. Green, SDF-1; red, CD3; and blue, nuclei. Representative data from two arthritic mice are shown.

\section{Abbreviations}

IIC: type II collagen; CIA: collagen-induced arthritis; KO: knockout; LN: lymph node; RA: rheumatoid arthritis.

\section{Acknowledgements}

We thank Ms. Tomoko Ando in the Division of Cancer Cell Research, Institute of Medical Science, University of Tokyo, for her helpful support for the initial setting of immunohistochemical analysis. We thank all the members of the laboratory for their excellent animal care. This research was supported by the Core Research for Evolutional Science \& Technology program of the Japan Science and Technology Agency, and grants from the Ministry of Education, Science, Sport, and Culture of Japan.

\section{Author details}

'Laboratory of Molecular Pathogenesis, Center for Experimental Medicine and Systems Biology, Institute of Medical Science, University of Tokyo, 4-6-1 Shirokanedai, Minato-ku, Tokyo 108-8639, Japan. ${ }^{2}$ Current address:

Department of Anatomy, College of Medicine, Korea University, 126-1, 5-Ga, Anam-Dong, Sungbuk-Gu, Seoul, Korea. ${ }^{3}$ Division of Molecular Pathology, Institute of Medical Science, University of Tokyo, 4-6-1 Shirokanedai, Minatoku, Tokyo 108-8639, Japan. ${ }^{4}$ Core Research for Evolutional Science and Technology (CREST), Japan Science and Technology Agency, Saitama 3320012, Japan.

\section{Authors' contributions}

SC mainly contributed throughout this work in collaboration with $\mathrm{KS}, \mathrm{NF}$, and SS. Immunohistochemical analysis was operated in collaboration with

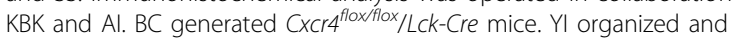
supervised the project and edited the draft manuscript. All authors read and approved the final manuscript.

\section{Competing interests}

The authors declare that they have no competing interests.

Received: 18 November 2009 Revised: 17 July 2010

Accepted: 12 October 2010 Published: 12 October 2010

\section{References}

1. Firestein GS: Evolving concepts of rheumatoid arthritis. Nature 2003, 423:356-361.

2. Zanelli E, Gonzalez-Gay MA, David CS: Could HLA-DRB1 be the protective locus in rheumatoid arthritis. Immunol Today 1995, 16:274-278.

3. Iwakura Y: Roles of IL-1 in the development of rheumatoid arthritis: consideration from mouse models. Cytokine Growth Factor Rev 2002, 13:341-355.

4. Trentham DE, Townes AS, Kang AH: Autoimmunity to type II collagen an experimental model of arthritis. J Exp Med 1977, 146:857-868.

5. Luross JA, Williams NA: The genetic and immunopathological processes underlying collagen-induced arthritis. Immunology 2001, 103:407-416.

6. Murdoch C: CXCR4: chemokine receptor extraordinaire. Immunol Rev 2000, 177:175-184

7. Egawa T, Kawabata K, Kawamoto H, Amada K, Okamoto R, Fujii N Kishimoto T, Katsura $Y$, Nagasawa T: The earliest stages of B cell development require a chemokine stromal cell-derived factor/pre-B cell growth-stimulating factor. Immunity 2001, 15:323-334.

8. Broxmeyer HE: Chemokines in hematopoiesis. Curr Opin Hematol 2008, 15:49-58.
9. Ara T, Itoi M, Kawabata K, Egawa T, Tokoyoda K, Sugiyama T, Fujii N, Amagai T, Nagasawa T: A role of CXC chemokine ligand 12/stromal cellderived factor-1/pre-B cell growth stimulating factor and its receptor CXCR4 in fetal and adult T cell development in vivo. I Immunol 2003, 170:4649-4655.

10. Kumar A, Humphreys T, Kremer K, Bramati P, Bradfield L, Edgar C, Hedin K: CXCR4 physically associates with the $\mathrm{T}$ cell receptor to signal in $\mathrm{T}$ cells. Immunity 2006, 25:213-224.

11. Nanki T, Hayashida K, El-Gabalawy HS, Suson S, Shi K, Girschick HJ, Yavuz S, Lipsky PE: Stromal cell-derived factor-1-CXC chemokine receptor 4 interactions play a central role in $\mathrm{CD} 4+\mathrm{T}$ cell accumulation in rheumatoid arthritis synovium. J Immunol 2000, 165:6590-6598.

12. Bradfield PF, Amft N, Vernon-Wilson E, Exley AE, Parsonage G, Rainger GE, Nash GB, Thomas AM, Simmons DL, Salmon M, Buckley CD: Rheumatoid fibroblast-like synoviocytes overexpress the chemokine stromal cellderived factor 1 (CXCL12), which supports distinct patterns and rates of CD4+ and CD8+ T cell migration within synovial tissue. Arthritis Rheum 2003, 48:2472-2482.

13. Burman A, Haworth $\mathrm{O}$, Hardie DL, Amft EN, Siewert C, Jackson DG, Salmon M, Buckley CD: A chemokine-dependent stromal induction mechanism for aberrant lymphocyte accumulation and compromised lymphatic return in rheumatoid arthritis. I Immunol 2005, 174:1693-1700.

14. Bleul CC, Farzan M, Choe H, Parolin C, Clark-Lewis I, Sodroski J, Springer TA: The lymphocyte chemoattractant SDF-1 is a ligand for LESTR/fusin and blocks HIV-1 entry. Nature 1996, 382:829-833.

15. Nagasawa T, Hirota S, Tachibana K, Takakura N, Nishikawa S, Kitamura Y, Yoshida N, Kikutani H, Kishimoto T: Defects of B-cell lymphopoiesis and bone-marrow myelopoiesis in mice lacking the CXC chemokine PBSF/ SDF-1. Nature 1996, 382:635-638.

16. Zou YR, Kottmann AH, Kuroda M, Taniuchi I, Littman DR: Function of the chemokine receptor CXCR4 in haematopoiesis and in cerebellar development. Nature 1998, 393:595-599.

17. Choi BI, Iwakura Y: Functional studies of chemokine receptor; CXCR4, with condtional knockout technique. Academic Dissertation. Graduate School of Science, University of Tokyo, Department of Biophysics and Biochemistry 2000

18. Takahama Y, Ohishi K, Tokoro Y, Sugawara T, Yoshimura Y, Okabe M, Kinoshita T, Takeda J: Functional competence of T cells in the absence of glycosylphosphatidylinositol-anchored proteins caused by $T$ cell-specific disruption of the Pig-a gene. Eur J Immunol 1998, 28:2159-2166.

19. Saijo S, Asano M, Horai R, Yamamoto H, Iwakura Y: Suppression of autoimmune arthritis in interleukin-1-deficient mice in which $\mathrm{T}$ cell activation is impaired due to low levels of CD40 ligand and OX40 expression on T cells. Arthritis Rheum 2002, 46:33-544.

20. Nakae S, Nambu A, Sudo K, Iwakura Y: Suppression of immune induction of collagen-induced arthritis in IL-17-deficient mice. J Immunol 2003, 171:6173-6177.

21. Frevert CW, Wong VA, Goodman RB, Goodwin R, Martin TR: Rapid fluorescence-based measurement of neutrophil migration in vitro. $J$ Immunol Methods 1998, 213:41-52.

22. Harvey W, Silva J: ${ }^{51} \mathrm{Cr}$ labeling of concentrated phagocytes. J Nucl Med 1973, 14:890-894.

23. Ghani S, Feuerer M, Doebis C, Lauer U, Loddenkemper C, Huehn J, Hamann A, Syrbe U: T cells as pioneers: antigen-specific T cells condition inflamed sites for high-rate antigen-non-specific effector cell recruitment. Immunology 2009, 128:e870-e880.

24. Siegmund K, Feuerer M, Siewert C, Ghani S, Haubold U, Dankof A, Krenn V, Schön MP, Scheffold A, Lowe JB, Hamann A, Syrbe U, Huehn J: Migration matters: regulatory T-cell compartmentalization determines suppressive activity in vivo. Blood 2005, 106:3097-3104.

25. Ara T, Tokoyoda K, Sugiyama T, Egawa T, Kawabata K, Nagasawa T: Longterm hematopoietic stem cells require stromal cell-derived factor- 1 for colonizing bone marrow during ontogeny. Immunity 2003, 19:257-267.

26. Kawabata K, Ujikawa M, Egawa T, Kawamoto H, Tachibana K, lizasa H, Katsura Y, Kishimoto T, Nagasawa T: A cell-autonomous requirement for CXCR4 in long-term lymphoid and myeloid reconstitution. Proc Natl Acad Sci USA 1999, 96:5663-5667.

27. Suzuki Y, Rahman M, Mitsuya H: Diverse transcriptional response of CD4 (+) T cells to stromal cell-derived factor (SDF)-1: cell survival promotion and priming effects of SDF-1 on CD4(+) T cells. J Immunol 2001, 167:3064-3073. 
28. Nanki T, Lipsky PE: Cutting edge: stromal cell-derived factor-1 is a costimulator for CD4+ T cell activation. J Immunol 2000, 164:5010-5014.

29. Brand DD, Kang AH, Rosloniec EF: Immunopathogenesis of collagen arthritis. Springer Semin Immunopathol 2003, 25:3-18.

30. Protocol for the successful induction of collagen-induced arthritis in mice. [http://www.chondrex.com/uploads/Mouse_CIA.pdf].

31. Holmdahl R, Andersson M, Goldschmidt T, Gustafsson K, Jansson L, Mo J: Type II collagen autoimmunity in animals and provocations leading to arthritis. Immunol Rev 1990, 118:193-232.

32. Huang J, Vestberg M, Minguela A, Holmdahl R, Ward E: Analysis of autoreactive $\mathrm{T}$ cells associated with murine collagen-induced arthritis using peptide-MHC multimers. Int Immunol 2004, 16:283-293.

33. Michaëlsson $E$, Andersson M, Engström A, Holmdahl R: Identification of an immunodominant type-Il collagen peptide recognized by $\mathrm{T}$ cells in $\mathrm{H}-2 \mathrm{q}$ mice: self-tolerance at the level of determinant selection. Eur J Immunol 1992, 22:1819-1825.

34. Terato K, DeArmey D, Ye X, Griffiths M, Cremer M: The mechanism of autoantibody formation to cartilage in rheumatoid arthritis: possible cross-reaction of antibodies to dietary collagens with autologous type II collagen. Clin Immunol Immunopathol 1996, 79:142-154.

35. Shadidi KR, Aarvak T, Henriksen JE, Natvig JB, Thompson KM: The chemokines CCL5, CCL2 and CXCL12 play significant roles in the migration of Th1 cells into rheumatoid synovial tissue. Scand J Immunol 2003, 57:192-198.

36. Buckley CD, Amft N, Bradfield PF, Pilling D, Ross E, Arenzana-Seisdedos F, Amara A, Curnow SJ, Lord JM, Scheel-Toellner D, Salmon M: Persistent induction of the chemokine receptor CXCR4 by TGF-beta 1 on synovial $T$ cells contributes to their accumulation within the rheumatoid synovium. J Immunol 2000, 165:3423-342.

37. Taylor P, Chu C, Plater-Zyberk C, Maini R: Transfer of type II collageninduced arthritis from DBA/1 to severe combined immunodeficiency mice can be prevented by blockade of Mac-1. Immunology 1996, 88:315-321.

38. Terato K, Hasty K, Reife R, Cremer M, Kang A, Stuart J: Induction of arthritis with monoclonal antibodies to collagen. J Immunol 1992, 148:2103-2108.

39. Nandakumar K, Bäcklund J, Vestberg M, Holmdahl R: Collagen type II (CII)specific antibodies induce arthritis in the absence of $T$ or $B$ cells but the arthritis progression is enhanced by Cll-reactive T cells. Arthritis Res Ther 2004, 6:R544-R550

40. Webb L, Walmsley M, Feldmann M: Prevention and amelioration of collagen-induced arthritis by blockade of the CD28 co-stimulatory pathway: requirement for both B7-1 and B7-2. Eur J Immunol 1996, 26:2320-2328.

41. Mitamura M, Nakano N, Yonekawa T, Shan L, Kaise T, Kobayashi T, Yamashita K, Kikkawa H, Kinoshita M: T cells are involved in the development of arthritis induced by anti-type II collagen antibody. Int Immunopharmacol 2007, 7:1360-1368.

42. Nigrovic $P$, Binstadt $B$, Monach $P$, Johnsen A, Gurish M, Iwakura $Y$, Benoist $C$, Mathis D, Lee D: Mast cells contribute to initiation of autoantibodymediated arthritis via IL-1. Proc Natl Acad Sci USA 2007, 104:2325-2330.

43. Patrussi $L$, Baldari CT: Intracellular mediators of CXCR4-dependent signaling in T cells. Immunol Lett 2008, 115:75-82.

44. Trampont $P$, Tosello-Trampont A, Shen $Y$, Duley A, Sutherland A, Bender T, Littman D, Ravichandran K: CXCR4 acts as a costimulator during thymic beta-selection. Nat Immunol 2010, 11:162-170.

45. Kim K, Cho M, Kim H, Ju J, Park M, Oh H, Kim J, Park S, Lee S, Kim H: Upregulation of stromal cell-derived factor 1 (CXCL12) production in rheumatoid synovial fibroblasts through interactions with $\mathrm{T}$ lymphocytes: role of interleukin-17 and CD40L-CD40 interaction. Arthritis Rheum 2007, 56:1076-1086.

46. Park C, Morel J, Amin M, Connors M, Harlow L, Koch A: Evidence of IL-18 as a novel angiogenic mediator. J Immunol 2001, 167:1644-1653.

47. Nanki T, Takada K, Komano Y, Morio T, Kanegane H, Nakajima A, Lipsky P, Miyasaka N: Chemokine receptor expression and functional effects of chemokines on B cells: implication in the pathogenesis of rheumatoid arthritis. Arthritis Res Ther 2009, 11:R149.

48. Grassi F, Cristino S, Toneguzzi S, Piacentini A, Facchini A, Lisignoli G: CXCL12 chemokine up-regulates bone resorption and MMP-9 release by human osteoclasts: CXCL12 levels are increased in synovial and bone tissue of rheumatoid arthritis patients. J Cell Physiol 2004, 199:244-251.
49. Kanbe K, Takagishi K, Chen Q: Stimulation of matrix metalloprotease 3 release from human chondrocytes by the interaction of stromal cellderived factor 1 and CXC chemokine receptor 4. Arthritis Rheum 2002, 46:130-137.

50. Pablos J, Santiago B, Galindo M, Torres C, Brehmer M, Blanco F, GarcíaLázaro F: Synoviocyte-derived CXCL12 is displayed on endothelium and induces angiogenesis in rheumatoid arthritis. J Immunol 2003, 170:2147-2152.

51. Habu K, Nakayama-Yamada J, Asano M, Saijo S, Itagaki K, Horai R, Yamamoto H, Sekiguchi T, Nosaka T, Hatanaka M, Iwakura Y: The human T cell leukemia virus type l-tax gene is responsible for the development of both inflammatory polyarthropathy resembling rheumatoid arthritis and noninflammatory ankylotic arthropathy in transgenic mice. J Immunol 1999, 162:2956-2963.

\section{doi:10.1186/ar3158}

Cite this article as: Chung et al:: CXC chemokine receptor 4 expressed in $T$ cells plays an important role in the development of collageninduced arthritis. Arthritis Research \& Therapy 2010 12:R188.

\section{Submit your next manuscript to BioMed Central and take full advantage of:}

- Convenient online submission

- Thorough peer review

- No space constraints or color figure charges

- Immediate publication on acceptance

- Inclusion in PubMed, CAS, Scopus and Google Scholar

- Research which is freely available for redistribution

Submit your manuscript at www.biomedcentral com/submit
C) Biomed Central 